\title{
28. RESIDUAL HYDROCARBON GASES IN CANNED CORE MATERIAL FROM HOLES 379A AND 380A, LEG 42B
}

\author{
Richard D. Mclver, Exxon Production Research Company, Houston, Texas
}

\begin{abstract}
Nine samples, eight from Hole 379A and one from Hole 380A, of sediment specifically canned for determination of residual gases contained the moderate amounts of hydrocarbon gas, virtually all of which was methane. These quantities are consistent with values detained from previous analysis of samples from earlier legs. Four additional samples from Holes 380 and $380 \mathrm{~A}$, collected and frozen for organic geochemistry, had moderate amounts of predominantly amorphous kerogen and were at a low state of thermal alteration (about 2) in the 1 to 5 alteration index scale, which was also evidenced by the low hydrocarbon to total bitumen ratio of the solvent extractables.
\end{abstract}

\section{BACKGROUND}

Shipboard personnel have frequently noted gas in the deep-sea muds in freshly recovered cores because it causes substantial expansion of the sediment and formation of gas gaps up to $15 \mathrm{~cm}$ long along the length of some cores.

This gas is of great interest both as to its origin as well as to the hazard it may represent. The composition of the gas is now carefully monitored to determine the ratio of methane to heavier gases; if the ratio of methane to the ethane-and-heavier fraction falls below $500-600$, it is judged that the organic matter in the sediments is experiencing the very onset of thermal cracking and gas volumes could increase rapidly. Thus the hazards of further drilling at the particular site must be weighed carefully.

The gas is mostly methane, probably produced microbially (Claypool et al., 1973), but quantitative estimates of the amounts per unit volume of sediment or the amount related to solubilities in water under down-hole conditions have not been made. The observations "gassy" and "very gassy" are sometimes recorded. In one case, anomalously high seismic velocities in a gassy section of the Blake-Bahama Outer Ridge and a strong-bottom paralleling reflector that cuts bedding plane reflections, together with mineralogical evidence reported by Lancelot and Ewing (1972), led to recognition that gas in the sediment immediately below the sea floor might occur as hydrate, a solid water-gas clathrate, that is theoretically stable under high pressures but above the freezing point of water (Katz, 1971).

In order to find out more about the gases, the DSDP Advisory Panel on Organic Geochemistry recommended that small portions of some of the cores be sealed in metal cans immediately after their recovery on deck so that at least the quantity of gas remaining in the sediment (i.e., residual gas) could be determined by methods established for drill cuttings (McIver, 1973). Of course, some of the gas is lost during the trip to the deck and subsequent handling, but the amounts have revealed the order-of-magnitude level of gases in place, as well as local variations.

Prior to collection of canned samples on Leg 42, about 125 samples from 22 sites had been collected and analyzed. The results are summarized in histogram form at the top of Figure 1. In every case the gas is virtually all methane. There was no apparent trend with depth or age, nor any correlation with organic carbon contents. The distribution is bimodal. Lower contents of gas (e.g., in Legs 18, 21, and 29) may be due to low gas-generating capability of the sediment, but, in some cases, probably reflect longer exposure to the atmosphere before canning, or poor seals, or even leaks in the cans. In almost every shipment there are a few cans with evidence of leaks (rust and corrosion at one or more points of the seal), and it is possible that other cans had undetected leaks.

\section{RESULTS}

The nine samples from Leg 42B were analyzed by our standard procedures (McIver, 1973). Results are listed, together with sample locations and organic carbon contents, in Table 1. The residual gas contents are also compared on Figure 1 with those from canned sediments from earlier legs. The 9 results are quite normal; they coincide with the higher and larger mode of the histogram, or are perhaps a little less gassy on the average than the average of that mode. In other words, they are not unusual.

Four other samples, these frozen shortly after coring, were also obtained for more conventional determinations of kerogen (Staplin, 1969) and heavy hydrocarbon (Koons et al., 1969). Results of this work are presented in Tables 2 and 3. The sediments are not unusual. Organic carbon, predominantly amorphous, has moderate concentrations. The high bitumen contents suggest that the sediments could be good sources of oil; but their low alteration indexes and low ratios of hydrocarbon to bitumens show that they have 


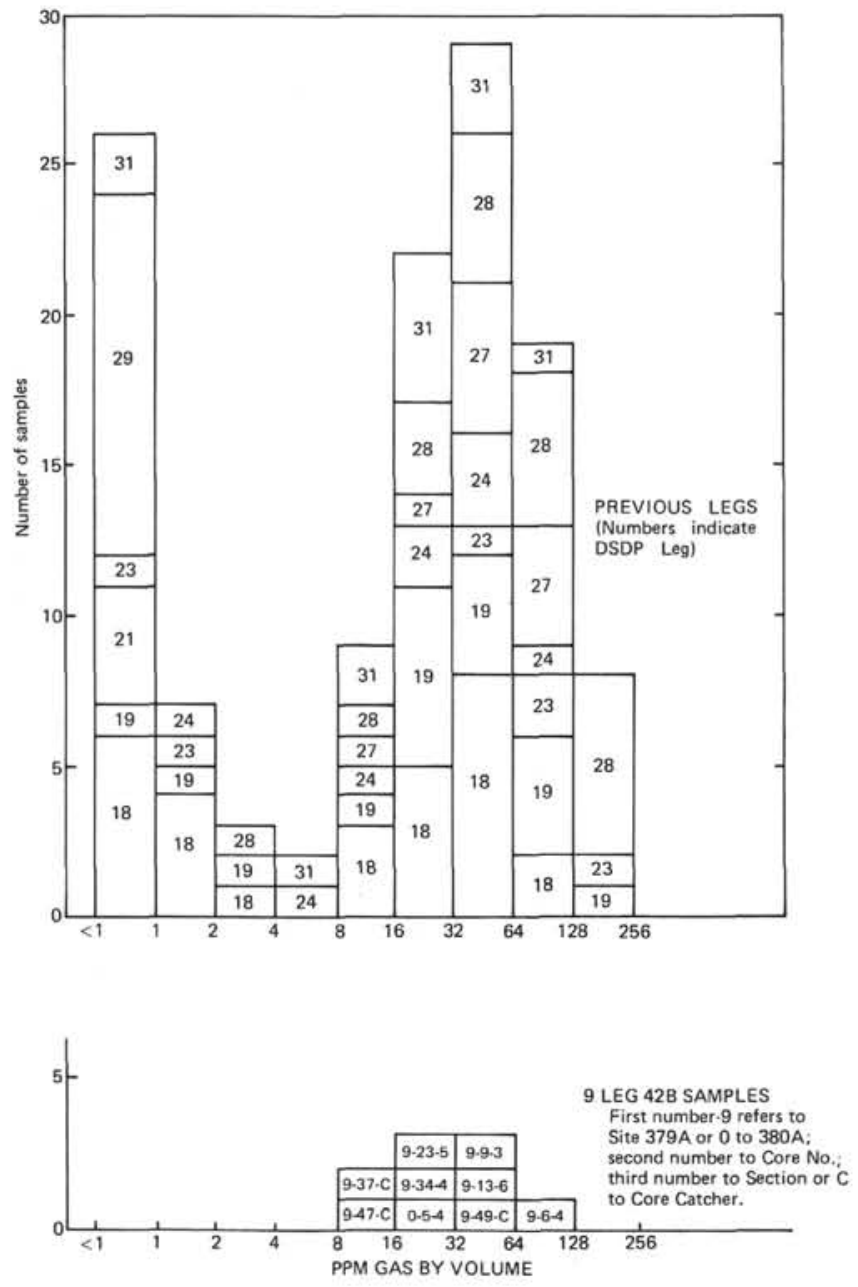

Figure 1. Comparison of Leg $42 B$ residual gas contents of canned sediments with previous results. not experienced enough thermal stress to produce enough hydrocarbon for significant hydrocarbon migration to occur, i.e., they are not now nor never have been sources.

\section{ACKNOWLEDGMENTS}

The author thanks Ralph Pokluda, Harvey Fry, and Jim Morgan who assisted with sample handling and analysis, and Exxon Production Research Company for their continuing support of research on DSDP cores, and for their permission to publish this report. Also special thanks goes to M.A. Rogers who reviewed this contribution and made helpful suggestions.

\section{REFERENCES}

Claypool, G.E., Presley, B.J., and Kaplan, I.R., 1973. Gas analysis in sediment sample from Legs $10,11,13,14,15$, 18, and 19. In Creager, J.S., Scholl, D.W., et al., Initial Reports of the Deep Sea Drilling Project, Volume 19: Washington (U.S. Government Printing Office), p. 879884.

Katz, D.L., 1971. Depths to which frozen gas fields (gas hydrates) may be expected: J. Petrol. Technol., v. 23, p. 419 .

Koons, C. B., et al., 1969. Data and discussion of analyses by Esso Production Research Company, including $\mathrm{C}^{12} / \mathrm{C}^{13}$ ratios. In Ewing, M.W., et al., Initial Reports of the Deep Sea Drilling Project, Volume 1: Washington (U.S. Government Printing Office), p. 478-489.

Lancelot, Y. and Ewing, J.I., 1972. Correlation of natural gas zonation and carbonate diageneses in Tertiary sediments from the northwest Atlantic. In Hollister, C.D., Ewing, J.I., et al., Initial Reports of the Deep Sea Drilling Project, Volume 11: Washington (U.S. Government Printing Office), p. 791-800.

Mclver, R.D., 1973 . Hydrocarbons in canned muds from Sites 185, 186, 189 and 191-Leg 19. In Creager, J.S., Scholl, D.W., et al., Initial Reports of the Deep Sea Drilling Project, Volume 19: Washington (U.S. Government Printing Office), p. 875-878.

Staplin, F.L., 1969. Sedimentary organic matter, organic metamorphism, and oil and gas occurrence: Canadian Petrol. Geol. Bull., v. 17, p. 47-66. 
TABLE 1

Hydrocarbon Gas in Canned Core Samples

\begin{tabular}{|c|c|c|c|c|c|c|c|}
\hline \multirow[b]{2}{*}{ Hole } & \multirow[b]{2}{*}{ Core } & \multirow[b]{2}{*}{ Section } & \multirow[b]{2}{*}{ Position } & \multirow[t]{2}{*}{$\%$ Organic Carbon } & \multicolumn{3}{|c|}{ Hydrocarbon Gas (ppm by vol.) } \\
\hline & & & & & Total & Methane & Per Cent Methane \\
\hline $379 \mathrm{~A}$ & 6 & 4 & Bottom & 0.30 & 74,100 & 73,800 & 99.6 \\
\hline $379 \mathrm{~A}$ & 9 & 3 & Bottom & 0.38 & 53,300 & 53,000 & 99.4 \\
\hline $379 \mathrm{~A}$ & 13 & 6 & Bottom & 0.16 & 63,600 & 63,300 & 99.5 \\
\hline $379 \mathrm{~A}$ & 23 & 5 & Bottom & 0.38 & 22,100 & 22,000 & 99.5 \\
\hline $379 \mathrm{~A}$ & 34 & 4 & Bottom & 0.30 & 20,400 & 20,200 & 99.0 \\
\hline $379 \mathrm{~A}$ & 37 & - & Bottom & 0.16 & 11,500 & 11,400 & 99.1 \\
\hline $379 \mathrm{~A}$ & 47 & - & Bottom & 0.08 & 12,200 & 12,100 & 99.2 \\
\hline $379 \mathrm{~A}$ & 49 & - & Bottom & 0.64 & 38,700 & 38,400 & 99.2 \\
\hline $380 \mathrm{~A}$ & 5 & 4 & Bottom & 1.46 & 27,500 & 27,300 & 99.3 \\
\hline
\end{tabular}

TABLE 2

Heavy Hydrocarbons in Frozen Cores

\begin{tabular}{lccc}
\hline $\begin{array}{c}\text { Sample } \\
\text { (Interval in cm) }\end{array}$ & \% Organic Carbon & $\begin{array}{c}\text { Total Extract } \\
\text { ppm (wt) }\end{array}$ & $\begin{array}{c}\text { Hydrocarbons } \\
\text { ppm (wt) }\end{array}$ \\
\hline $380-17-5,90-95$ & 0.64 & 630 & 30 \\
$380-25-3,86-92$ & 0.70 & 645 & 22 \\
380 A-2-5, 36-43 & 0.87 & 337 & 24 \\
380 A-63-1, 15-18 & 0.74 & 1393 & 135 \\
\hline
\end{tabular}

TABLE 3

Kerogen in Frozen Cores

\begin{tabular}{|c|c|c|c|c|}
\hline \multirow{2}{*}{$\begin{array}{c}\text { Sample } \\
\text { (Interval in } \mathrm{cm} \text { ) }\end{array}$} & \multicolumn{3}{|c|}{ Description of Insoluble Organic Matter (kerogen) } & \multirow{2}{*}{$\begin{array}{c}\text { Degree of } \\
\text { Maturation }\end{array}$} \\
\hline & Primary & Secondary & Other & \\
\hline $380-17-5,90-95$ & Amorphous & Herbaceous-woody- & - & $1+/ 2-$ \\
\hline $380-25-3,96-92$ & Woody-coaly & Amorphous-herbaceous & - & $1+/ 2-$ \\
\hline $380 \mathrm{~A}-2-5,36-43$ & $\begin{array}{l}\text { Amorphous- } \\
\text { woody-coaly }\end{array}$ & Herbaceous & - & $1+/ 2-$ \\
\hline $380 \mathrm{~A}-63-1,15-18$ & Amorphous & Herbaceous & Woody (coaly) & $1+/ 2-$ \\
\hline
\end{tabular}

